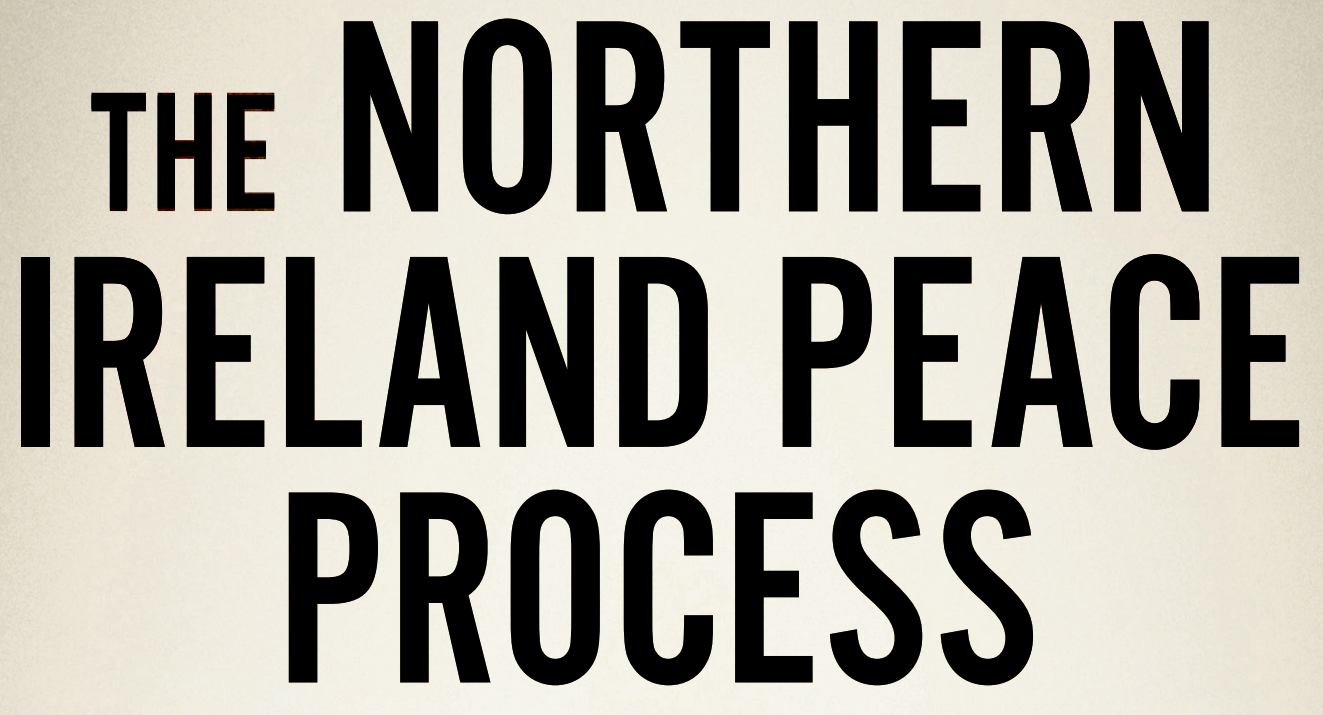

FROM ARMED CONFLICT TO BREXIT

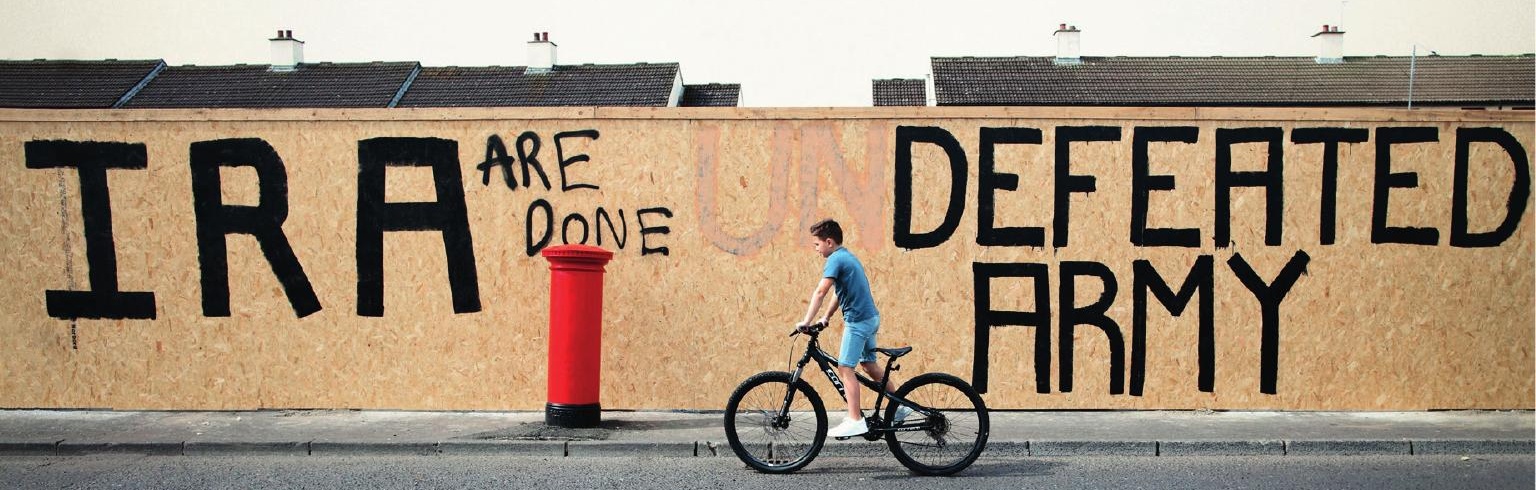

EAMONN O'KANE. 
The Northern Ireland peace process

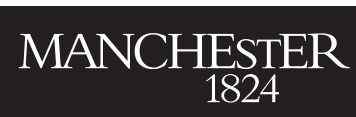

Manchester University Press 
Eamonn O'Kane - 9781526116635 Downloaded from manchesterhive.com at 04/26/2023 12:15: 02PM via free access 


\title{
The Northern Ireland peace process
}

\section{From armed conflict to Brexit}

\author{
Eamonn O'Kane
}

Manchester University Press 
Copyright (C) Eamonn O’Kane 2021

The right of Eamonn O'Kane to be identified as the author of this work has been asserted by them in accordance with the Copyright, Designs and Patents Act 1988.

Published by Manchester University Press

Oxford Road, Manchester M13 9PL

www.manchesteruniversitypress.co.uk

British Library Cataloguing-in-Publication Data

A catalogue record for this book is available from the British Library

ISBN 9780719090837 hardback

First published 2021

The publisher has no responsibility for the persistence or accuracy of URLs for any external or third-party internet websites referred to in this book, and does not guarantee that any content on such websites is, or will remain, accurate or appropriate.

Cover image: Paul Faith / Contributor

Typeset

by Sunrise Setting Ltd, Brixham 